\title{
Three-dimensional Modeling of Anode-supported Planar SOFC With Direct Internal Reforming
}

\author{
Zuopeng Qu ${ }^{\mathrm{a}}$, P. V. Aravind ${ }^{\mathrm{a}}$, Huaiyu Ye ${ }^{\mathrm{a}}$, N. J. J. Dekker ${ }^{\mathrm{b}}$, \\ N. Woudstra ${ }^{a}$, A. H. M Verkooijen ${ }^{a}$ \\ ${ }^{a}$ Department of Process \& Energy, Delft University of Technology, The Netherlands \\ ${ }^{b}$ Energy Research Centre of the Netherlands (ECN), The Netherlands
}

This paper presents a three-dimensional model of an anodesupported planar SOFC with corrugated bipolar plates serving as gas channels and current collector above the active area of the cell, based on the direct internal reforming reaction of methane and the electrochemical reaction of hydrogen. A co-flow system with gas mixture of methane, water vapor and a small amount of hydrogen as anode gas and air as cathode gas fed at an inlet temperature of 973K was modeled at a single cell unit level. A simple equation for the cell resistance with measured values for the quasi ohmic resistance is used for the calculation of the current density. The modeling results show the current density distribution and temperature profiles in the cell and gas concentrations profiles along the length of the cell channel. Furthermore, the temperature gradient inside the cell was investigated.

\section{Introduction}

Solid oxide fuel cells (SOFCs) operated at high temperature (normally $650-1100^{\circ} \mathrm{C}$ ) are attractive energy conversion devices which generate electricity and heat directly from a gaseous or gasified fuel by electrochemical combination of that fuel and oxidant efficiently without the restriction of Carnot's law. In addition to the high efficiency of the SOFC itself, hybrid systems of the SOFCs with other power generation expected to be one of the most efficient power generation systems. Therefore, great attention has been paid to SOFCs in recent years $(1,2)$.

In low temperature fuel cell systems, hydrogen as the preferred fuel is usually produced in an external reformer by steam reforming of hydrocarbons such as methane or natural gas. The endothermic steam reforming reaction takes place at high temperature over $800 \mathrm{~K}$ and the required heat normally will be supplied by combusting part of the fuel. This endows the SOFCs with the possibility to have the reforming reaction occurring internally by utilization of the heat generated by SOFCs. Compared with other fuel cell types, a major advantage of the SOFCs is the flexibility in the choice of fuels. With direct internal reforming, efficiency and simplicity of the SOFC system can be maximized (3).

However, the introduction of the internal steam reforming in SOFCs will bring the problem of large temperature gradients within the fuel cell. Steam reforming is a highly endothermic process, whereas the electrochemical oxidation is an exothermic reaction [4]. The reforming reaction for methane, the main component of natural gas, is shown in Eq. [1]. The associated water gas shift reaction [2] proceeds in parallel to reaction [1]. 


$$
\begin{array}{ll}
\mathrm{CH}_{4}+\mathrm{H}_{2} \mathrm{O} \rightleftharpoons \mathrm{CO}+3 \mathrm{H}_{2} & \Delta \mathrm{H}_{298}=+206 \mathrm{~kJ} / \mathrm{mol} \\
\mathrm{CO}+\mathrm{H}_{2} \mathrm{O} \rightleftharpoons \mathrm{CO}_{2}+\mathrm{H}_{2} & \Delta \mathrm{H}_{298}=-41 \mathrm{~kJ} / \mathrm{mol}
\end{array}
$$

The heat used for sustaining the endothermic reforming process is supplied by the exothermic electrochemical reactions (3) and (4). However, the available $\Delta H$ from the electrochemical reactions is only partly converted into heat, and most of the enthalpy change is used to generate electricity

$$
\begin{array}{ll}
\mathrm{H}_{2}+\frac{1}{2} \mathrm{O}_{2} \rightarrow \mathrm{H}_{2} \mathrm{O} & \Delta \mathrm{H}_{298}=-241 \mathrm{~kJ} / \mathrm{mol} \\
\mathrm{CO}+\frac{1}{2} \mathrm{O}_{2} \rightarrow \mathrm{CO}_{2} & \Delta H_{298}=-283 \mathrm{~kJ} / \mathrm{mol}
\end{array}
$$

The combination of the strongly endothermic steam reforming reaction, the exothermic waster gas shift and electrochemical reactions will cause significant temperature changes along the cell, which can result in steep temperature gradients. Temperature gradients can cause severe thermal stresses in the solid parts of the cell and potential system failure from crack formation which will seriously reduce the life time of SOFCs (5).

In order to better understand the operation of SOFCs and predict the possible failure of it, a number of theoretical models have been developed. Studies of one, two or three dimensional models with various configurations and geometries have been published for either internal or external reforming (5-12). However, most of the models so far focus on only one or two dimensions; three dimensional models for complicated geometries are rarely reported. These models also have the deficiencies of assuming reactions taking place in the gas-phase or surface area instead of the solid-phase volumetric reactions. Some models only consider the cell as a single solid phase and neglect the effect of the diffusion of gases through the porous electrodes. The resistance used in the electrochemical model is calculated theoretically rather than experimentally. The limitations of these models may affect the reliability of the results.

In this study, a three-dimensional model of an anode-supported planar SOFC with direct internal reforming reaction of methane has been developed to investigate the temperature gradients within a single channel of a cell for the proposed design. The reforming process, electrochemical reactions, heat and mass transfer phenomena between the solid and gas phases have all been included in the cell model. The conservation equations are solved by using commercial computational fluid dynamics (CFD) software Fluent; the methane steam reforming kinetics and the electrochemical reaction are simulated by external user defined subroutines. The electrochemical model utilizes a simple equation for the cell resistance with experimentally determined values of the different parameters for calculating the electrochemical parameters. The detailed variation of species concentrations such as $\mathrm{H}_{2}, \mathrm{CH}_{4}, \mathrm{CO}, \mathrm{H}_{2} \mathrm{O}$ and $\mathrm{CO}_{2}$, distribution of current density and temperature profile etc. over the cell are presented and discussed.

\section{SOFC Model Development}

\section{Model Specifications}

The geometric model used in this work is shown in Fig. 1. The proposed configuration is based on anode-supported planar SOFC with corrugated bipolar plates 
serving as gas channels and current collector above and below the active area of the cell. The model developed in this work considers a single cell unit in the stack. The simulation of the single channel is supposed to be representative for the behavior of the whole stack, except the channels at the edges of the stack where boundary conditions and active cell area could be different.

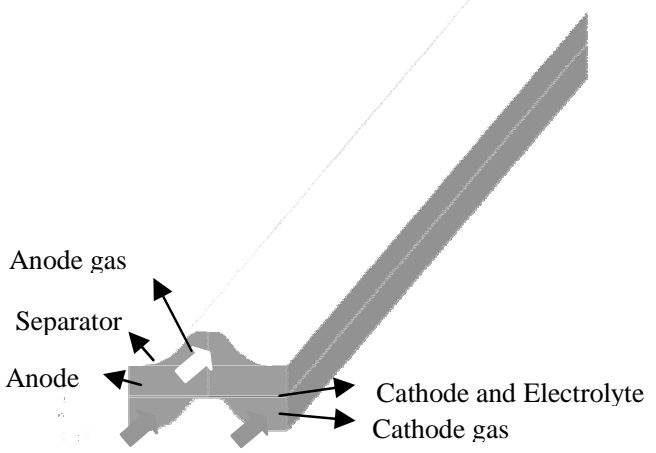

(a)

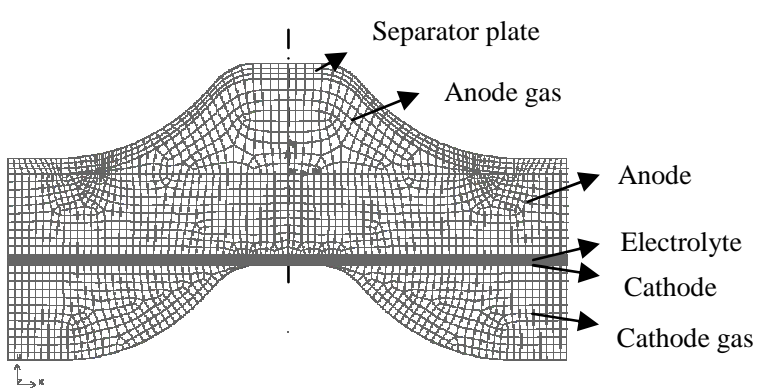

(b)

Figure 1. Geometric model: (a) three dimensional view of the modeled one single unit channel in the cell (b) the front view of the model with grids

TABLE I. Model specifications and input parameters.

\begin{tabular}{|c|c|c|}
\hline & Specifications & Input data \\
\hline $\begin{array}{l}\text { Geometric } \\
\text { parameters }\end{array}$ & $\begin{array}{l}\text { Anode thickness }\left(\tau_{\mathrm{a}}\right) \\
\text { Cathode thickness }\left(\tau_{\mathrm{c}}\right) \\
\text { Electrode thickness }\left(\tau_{\mathrm{e}}\right) \\
\text { Interconnect thickness }\left(\tau_{\mathrm{i}}\right) \\
\text { Cell length }(\mathrm{L}) \\
\text { Unit channel width }(\mathrm{W}) \\
\text { Fuel channel height }\left(\mathrm{h}_{\mathrm{f}}\right) \\
\text { Air channel height }\left(\mathrm{h}_{\mathrm{a}}\right) \\
\end{array}$ & $\begin{array}{c}0.55 \mathrm{~mm} \\
0.03 \mathrm{~mm} \\
0.01 \mathrm{~mm} \\
0.2 \mathrm{~mm} \\
112 \mathrm{~mm} \\
4 \mathrm{~mm} \\
0.6 \mathrm{~mm} \\
0.6 \mathrm{~mm} \\
\end{array}$ \\
\hline $\begin{array}{c}\text { Material } \\
\text { properties }\end{array}$ & $\begin{array}{l}\text { Anode density }\left(\rho_{A}\right) \\
\text { Anode thermal conductivity }\left(\lambda_{A}\right) \\
\text { Anode heat capacity }\left(C_{p, A}\right) \\
\text { Anode porosity }(\gamma) \\
\text { Cathode density }\left(\rho_{C}\right) \\
\text { Cathode thermal conductivity }\left(\lambda_{C}\right) \\
\text { Cathode heat capacity }\left(C_{p, C}\right) \\
\text { Cathode porosity }(\gamma) \\
\text { Electrolyte density }\left(\rho_{E}\right) \\
\text { Electrolyte thermal conductivity }\left(\lambda_{E}\right) \\
\text { Electrolyte heat capacity }\left(C_{p, E}\right)\end{array}$ & $\begin{array}{c}7740 \mathrm{~kg} \mathrm{~m}^{-3} \\
6 \mathrm{~W} \mathrm{~m}^{-1} \mathrm{~K}^{-1} \\
0.6 \mathrm{~kJ} \mathrm{~kg}^{-1} \mathrm{~K}^{-1} \\
30 \% \\
5300 \mathrm{~kg} \mathrm{~m}^{-3} \\
10 \mathrm{~W} \mathrm{~m}^{-1} \mathrm{~K}^{-1} \\
0.607 \mathrm{~kJ} \mathrm{~kg}^{-1} \mathrm{~K}^{-1} \\
30 \% \\
6000 \mathrm{~kg} \mathrm{~m}^{-3} \\
2.7 \mathrm{~W} \mathrm{~m}^{-1} \mathrm{~K}^{-1} \\
0.4 \mathrm{~kJ} \mathrm{~kg}^{-1} \mathrm{~K}^{-1} \\
\end{array}$ \\
\hline $\begin{array}{l}\text { Operating } \\
\text { parameters }\end{array}$ & $\begin{array}{l}\text { Pressure }(P) \\
\text { Fuel inlet temperature }\left(\mathrm{T}_{\mathrm{f}} \text {, inlet }\right) \\
\text { Air inlet temperature }\left(\mathrm{T}_{\mathrm{a}} \text { inlet }\right) \\
\text { Top and bottom external wall } \\
\text { Operating voltage }\left(\mathrm{V}_{\text {cell }}\right) \\
\text { Fuel feed } \\
\text { Air feed } \\
\text { Air to fuel ratio } \\
\text { Fuel utilization }\left(\mathrm{U}_{\text {fuel }}\right) \\
\end{array}$ & $\begin{array}{c}1 \mathrm{bar} \\
973 \mathrm{~K} \\
973 \mathrm{~K} \\
\text { Adiabatic } \\
0.8 \mathrm{~V} \\
30 \% \mathrm{CH}_{4}, 60 \% \mathrm{H}_{2} \mathrm{O}, 10 \% \mathrm{H}_{2} \\
21 \% \mathrm{O}_{2}, 79 \% \mathrm{~N}_{2} \\
10 \\
0.85 \\
\end{array}$ \\
\hline $\begin{array}{l}\text { Electrochemical } \\
\text { parameters }\end{array}$ & $\begin{array}{l}\text { Activation energy }\left(\mathrm{E}_{\mathrm{a}}\right) \\
\text { Empirical parameter }\left(\mathrm{k}_{0}\right) \\
\text { Faraday constant }(\mathrm{F}) \\
\text { Universal gas constant }(\mathrm{R})\end{array}$ & $\begin{array}{c}-101248 \mathrm{~J} \mathrm{~mol}^{-1} \mathrm{~K}^{-1} \\
1.8870 \mathrm{e}^{-10} \mathrm{ohm} \mathrm{m}^{2} \\
96485 \mathrm{c} \\
8.314 \mathrm{~J} \mathrm{~mole}^{-1} \mathrm{~K}^{-1}\end{array}$ \\
\hline
\end{tabular}

As shown in Fig. 1a the present model is based on the co-flow design, in which anode gas and cathode gas flows on both sides of the cell in the same direction. Fig. 1b shows 
the cross section of the single cell unit and resulting grids for the calculation. The mesh is locally refined at the regions where the geometry changes dramatically. The cell is in the middle of the corrugated plates. The fuel gas channel is between the anode and the corrugated separator plate and on the other side the corresponding air channel is located between the cathode and separator plate. The specifications and some input data of the present model are summarized in table I.

\section{Thermo-fluid Model}

In this three-dimensional CFD modeling work, the solid and fluid (including porous part) domains are divided into many discrete meshes, shown in Fig. 1b. In each computational grid, the following conservation equations of mass, momentum, species and energy are solved by finite volume method.

$$
\begin{gathered}
\nabla \cdot(\rho \vec{v})=S_{\text {mass }} \\
\nabla \cdot(\rho \vec{v} \vec{v})+\nabla p-\nabla \cdot\left[\mu\left(\nabla \vec{v}+\nabla \vec{v}^{T}\right)-\frac{2 \mu}{3} \nabla \vec{v} I\right]=S_{M}
\end{gathered}
$$

The conservation equations of mass and momentum are shown in Eq. [5] and [6], respectively, where $S_{\text {mass }}$ is the mass source added to the continuous phase using userdefined sources. The electrodes in the cell are treated as porous media. The additional momentum source caused by the porous media in the model is contained in the term $S_{M}$.

Generally, the gas species transfer mainly by convection in the flow channels and diffusion in the porous electrodes. The species conservation can be expressed in Eq. [7].

$$
\nabla \cdot\left(\rho \vec{v} Y_{i}\right)=\nabla \cdot\left(\rho D_{i}^{e f f} \nabla Y_{i}\right)+S_{i}
$$

where $S_{i}$ is the species sources in the model, which include the net rate of the production of species $\mathrm{i}\left(\mathrm{H}_{2}, \mathrm{O}_{2}, \mathrm{H}_{2} \mathrm{O}, \mathrm{CH}_{4}, \mathrm{CO}, \mathrm{CO}_{2}, \mathrm{~N}_{2}\right)$ and the rate of the additional creation from user defined sources. $D_{i}^{e f f}$ is the effective diffusion coefficient.

Energy conservation equation is expressed as Eq. [8], where $k_{\text {eff }}$ is the effective thermal conductivity of the medium. For instance, in the porous electrodes the $k_{\text {eff }}$ can be calculated by using Eq. [9], where the $k_{f}$ and $k_{s}$ are the thermal conductivities of fluid and solid, and $\gamma$ is the porosity of the porous medium.

$$
\begin{gathered}
\nabla \cdot(\vec{v}(\rho E+p))=\nabla \cdot\left(k_{\text {eff }} \nabla T+\sum_{i} h_{i} \rho D_{i}^{e f f} \nabla Y_{i}+\left(\tau_{e f f} \cdot \vec{v}\right)\right)+S_{h} \\
k_{e f f}=\gamma k_{f}+(1-\gamma) k_{s}
\end{gathered}
$$

For the mass balance in the model the chemical species of $\mathrm{CH}_{4}, \mathrm{H}_{2} \mathrm{O}, \mathrm{CO}, \mathrm{H}_{2}$ and $\mathrm{CO}_{2}$ are considered in the anode side and $\mathrm{O}_{2}$ and $\mathrm{N}_{2}$ are at the cathode side. The steam reforming reaction [1] and water gas shift reaction take place in the anode of the cell under the formation of hydrogen. The electrochemical reaction of hydrogen occurs at the interface between the anode and the electrolyte. 
As for the heat balances, the single unit channel simulated in this work is assumed to be thermally isolated from bottom and top sides. The left and right sides of the cell unit are treated as symmetric boundaries. Heat is generated or withdrawn from the reaction in the anode and the reaction zone mentioned previously. No reaction takes place in the gas phase at the temperature of interest for this study. Heat is exchanged between the solid and the gas streams by convection and transport of the reactants and products from or through the anode and reaction zone. In the solid part of the cell, heat conduction is dominant. The gases flowing on each side of the cell will remove or provide heat from or to the cell through convection. The diffusion of gas species also contributes to the heat exchange between the cell and the gas phase. In this simulation the effect of the radiation heat transfer is not considered.

\section{Electrochemical Model}

The electrochemical model calculates the local current density in the cell. In SOFCs, the oxidant, which is oxygen in the air in this case, is fed into the cathode gas channel. At the cathode the oxidant reduction occurs, which can be expressed as Eq. [10]

$$
\frac{1}{2} \mathrm{O}_{2}+2 e^{-} \rightarrow \mathrm{O}^{2-}
$$

The oxygen ions generated at the cathode pass through the electrolyte and then take part in the electrochemical reaction at the active reaction area of the anode, which in this model is the thin layer of the anode close to the electrolyte. The previous research (15, 16) and experiments show the electrochemical oxidation of $\mathrm{H}_{2}$ is much faster than $\mathrm{CO}$. Therefore the electrochemical conversion rate of CO is negligible. In this work only the electrochemical reaction of hydrogen in Eq. [11] at anode is considered. The overall reaction is Eq. [3].

$$
\mathrm{H}_{2}+\mathrm{O}^{2-} \rightarrow \mathrm{H}_{2} \mathrm{O}+2 e^{-}
$$

The reversible cell voltage $\left(E_{\text {rev }}\right)$ is locally changing with gas composition and temperature at the electrodes, and can be determined by the Nernst Eq. [12] for the electrochemical oxidation of hydrogen.

$$
E_{\mathrm{rev}}=E_{\mathrm{H}_{2}}^{0}+\frac{R T}{2 F} \ln \left(\frac{p_{\mathrm{H}_{2}} p_{\mathrm{O}_{2}}{ }^{0.5}}{p_{\mathrm{H}_{2} \mathrm{O}}}\right)
$$

$E_{\mathrm{H}_{2}}^{0}$ stands for the standard potential for the hydrogen oxidation reaction at temperature $T$, and is the change of Gibbs free energy for the formation reaction of water divided by $2 F$, as shown in Eq. [13].

$$
E_{H_{2}}^{0}=\frac{\Delta \bar{g}_{f}}{2 F}
$$

$\mathrm{pH}_{2}, \mathrm{pO} 2, \mathrm{pH}_{2} \mathrm{O}$ and $\mathrm{R}$ represent the partial pressure of hydrogen, oxygen, water vapor and gas constant, respectively.

The open-circuit potential $\left(E_{\mathrm{rev}}\right)$ is the maximum voltage which can be achieved by a fuel cell under specific operation conditions. However, the voltage of an operating cell $\left(V_{\text {cell }}\right)$, equal to the voltage difference between the cathode and the anode, is lower than 
$E_{\text {rev }}$. The difference between the $E_{\text {rev }}$ and $V_{\text {cell }}$ is due to the internal resistances, electrode overpotential losses and contact resistances. In this work the resistance for the proposed cell is estimated from the experimentally measured I-V curve for a single cell. An empirical formula Eq. [15] was derived for estimating the value of the total local losses $\left(R_{\text {tot, loc }}\right)$ occurring in the operating cell, which is function of temperature $T$, where $\mathrm{k}_{0}, \mathrm{E}_{\mathrm{a}}$ and $\mathrm{R}$ are constants, summarized in table $\mathrm{I}$. Therefore, the operating cell voltage $\left(V_{\text {cell }}\right)$ can be expressed as Eq [14].

$$
V_{\text {cell }}=E_{\text {rev }}-i R_{\text {tot.loc }}
$$

Since the anode and steel parts in the stack are good conductors, a constant cell voltage of $0.8 \mathrm{~V}$ is assumed in this work. All the losses are in part responsible for the heat generated in an operating fuel cell and will be explained later.

$$
R_{t o t, l o c}=k_{0} \exp \left(\frac{-E_{a}}{R T}\right)
$$

The derived empirical formula of total resistance in the cell is valid in the temperature range between 675 and $800^{\circ} \mathrm{C}$. Finally the current density is calculated by Eq. [16].

$$
i=\frac{E_{r e v}-V_{c e l l}}{R_{t o t, l o c}}
$$

\section{$\underline{\text { Steam Reforming Reaction }}$}

The steam reforming (Eq. [1]) and water gas shift reactions (Eq. [2]) generates $\mathrm{H}_{2}$, $\mathrm{CO}$ and $\mathrm{H}_{2}$ and $\mathrm{CO}_{2}$, respectively. The generated hydrogen is consumed as fuel. The mechanism of steam reforming on the Ni cermet anodes of SOFCs follows a similar mechanism to conventional methane steam reforming, which has been widely studied. The internal reforming kinetics is an important parameter for the SOFC developers, which could be affected by many factors such as the material and manufacturing of anode, the partial pressure of methane and steam, the diffusion and temperature etc. and the kinetics of the reforming reaction at the SOFC operating conditions is also reported in many publications $(15,17-23)$.

$$
r_{C H_{4}}=k P_{C H_{4}} \exp \left(-E_{a} / R T\right)
$$

The steam reforming rate in this work was determined by the first order kinetic expression [17] derived by E. Achenbach, E. Riensche (23) based on the Ni/YSZ cermet anode, with an activation energy $\left(E_{a}\right)$ of $83 \mathrm{~kJ} \mathrm{~mol}^{-1}(9)$ and a pre-exponential constant ( $k$ ) of $1.01 \times 10^{12} \mathrm{~mol} \mathrm{~m}^{-3} \mathrm{~s}^{-1}(10)$.

It is found the water-gas shift reaction is close to equilibrium at high level of fuel utilization $(24,25)$. In this modeling, a pre-exponential factor $k_{w g s}$ is used for the calculation of water shift reaction rate according to Eq. [18] (9).

$$
r_{w g s}=k_{w g s} P_{C O}\left(1-\frac{P_{\mathrm{CO}_{2}} P_{\mathrm{H}_{2}} / P_{\mathrm{CO}} P_{\mathrm{H}_{2} \mathrm{O}}}{K_{e q, w g s}}\right)
$$




\section{Results and Discussion}

In this section, the model results for the gas species concentration and current density profiles along the length of the cell will be discussed. The temperature distributions at different locations within the cell along the length will be given and the resulting temperature gradient will be shown.

\section{$\underline{\text { Gas Species Concentrations }}$}

Fig. 2 shows the mole fraction profiles of gas species in the anode gas channel along the length of the cell unit. The concentrations of the gases are affected by the direct internal reforming reaction, water gas shift reaction at the anode and electrochemical reaction of hydrogen at the interface of anode and electrolyte. From the table I, we know at the inlet the fuel composition is $30 \%$ methane, $60 \%$ water and $10 \%$ hydrogen. Due to the high methane content at the entrance of the fuel cell, the reforming reaction is fast and the methane is consumed rapidly, accordingly, water is also reacted fast. Therefore, at the entrance of the fuel cell (within the first 20mm) strong decrease of concentrations of $\mathrm{CH}_{4}$ and $\mathrm{H}_{2} \mathrm{O}$ can be seen from Fig. 2. The methane in the fuel is almost depleted at around half way of the cell. Meanwhile, hydrogen has a corresponding increase until at the length of $30 \mathrm{~mm}$, where the hydrogen content in the channel reaches the peak of approximately $47 \%$. Correspondingly there is a minimum in the water concentration because water is consumed by the reforming reaction and produced by the electrochemical reaction. Afterwards, a rise of water and a decline of hydrogen content are observed because the oxidation of $\mathrm{H}_{2}$ dominates with more hydrogen generated from the previous fast reforming reaction. Distributions of $\mathrm{CO}$ and $\mathrm{CO}_{2}$ along the length of the fuel cell are in agreement with equilibrium except the inlet region, where $\mathrm{CO}$ is produced very fast by steam reforming reaction. At the exit of the fuel channel, all the methane has been consumed and the content of the gas stream is $15 \%$ hydrogen, $66 \%$ water, $5 \%$ carbon monoxide, $14 \%$ carbon dioxide. Therefore, the fuel utilization in this work is $85 \%$.

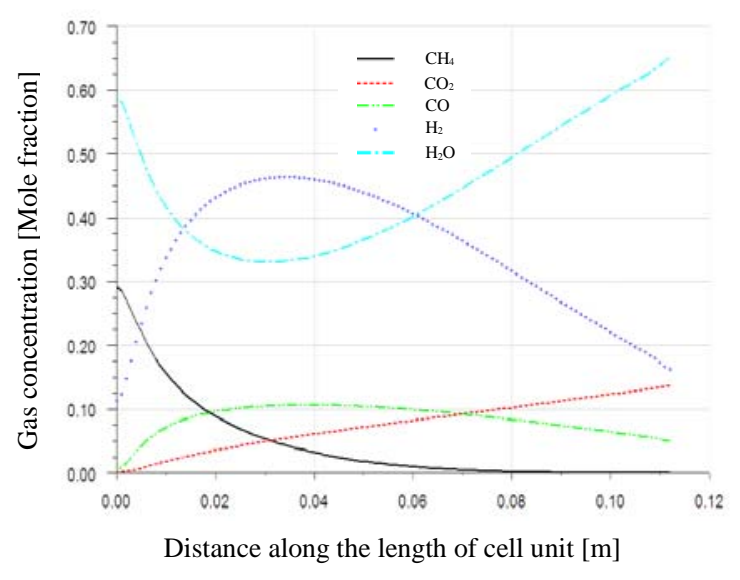

Figure 2. Gas species concentration in anode gas channel along the length of cell unit.

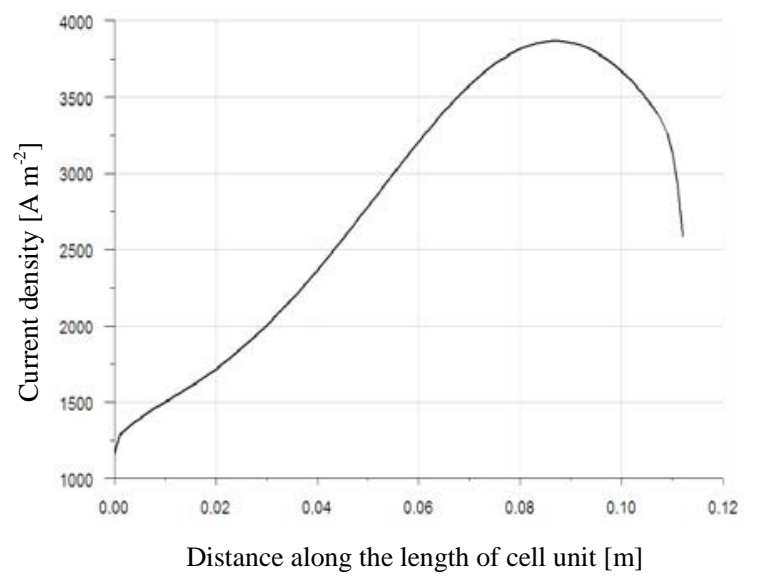

Figure 3. Current density distribution along the length of the cell unit.

\section{Current Density Profile}

Current density profile along the cell length is presented in Fig. 3. The current density increases from the beginning of the cell and reaches maximum at the length of $84 \mathrm{~mm}$ 
(three fourths of the total length). The current density, depending on many factors and operating parameters implemented into the model, is a function of the concentrations of gas species, the temperature and the cell operating voltage etc. In this work, for the proposed intermediate temperature SOFC, the inlet gas is supposed to be $973 \mathrm{~K}$ and the operating voltage 0.8 volt. The comparative low inlet temperature and high operating cell voltage makes the current density in this case is somewhat lower than the value generally reported.

\section{$\underline{\text { Temperature Distribution }}$}

The temperature profiles of fuel, air, cell and interconnect along the length of the cell unit are illustrated in Fig. 4. At the entrance of the cell, the average temperature of fuel in the anode gas channel shows a sharp drop from the $973 \mathrm{~K}$ at the inlet to minimum value of $908 \mathrm{~K}$ because of the strongly endothermic steam reforming reaction proceeding extremely fast. It can also be seen that although $65 \mathrm{~K}$ temperature difference take places at the inlet region in the anode gas phase, in the solid parts such as the cell and the interconnect plate the equivalent temperature decrease is only within $3 \mathrm{~K}$ because the anode in the cell structure is the location where the endothermic steam reforming reaction occurs and the thermal conductivities of these solid parts in the cell are high enough to rapidly distribute the heat relative to the heat transport between the cathode gas and the solid part by convection.

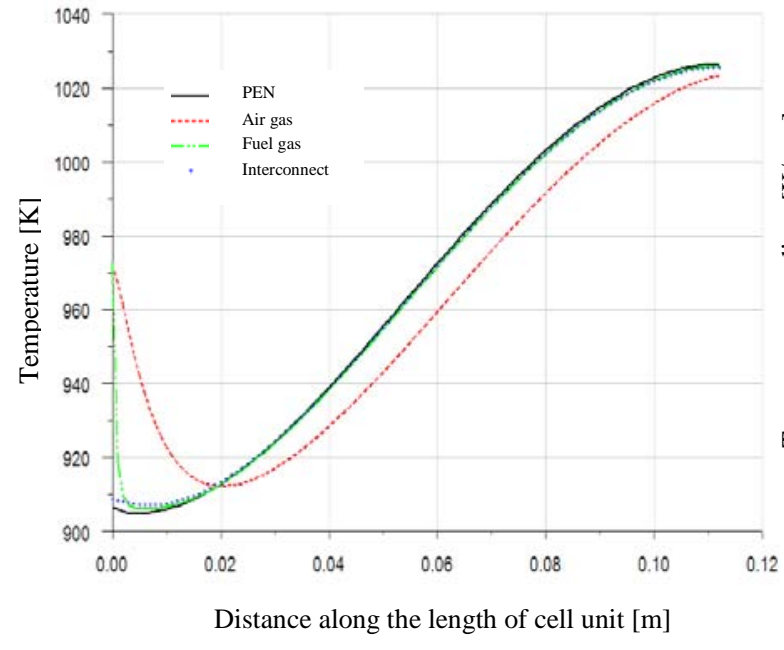

Fig. 4. Temperature profiles in the fuel, air, cell and interconnect along the length of the cell.

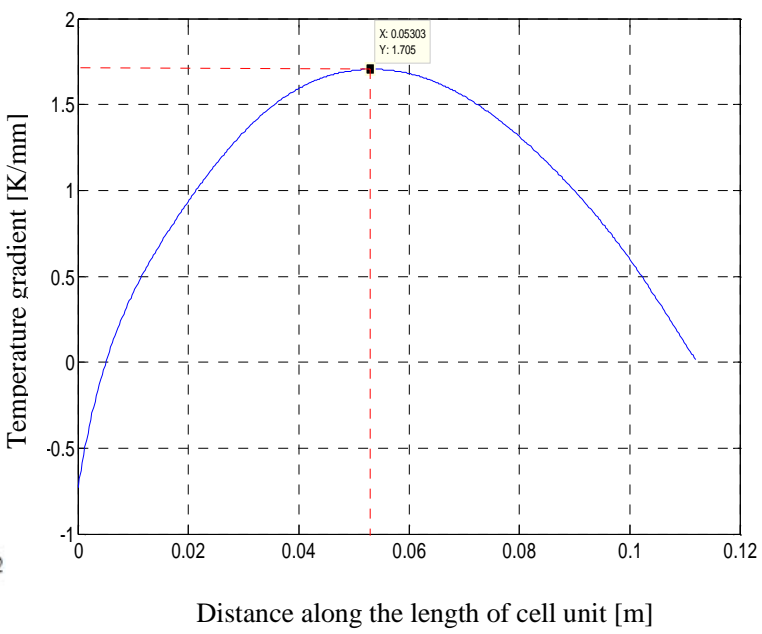

Fig. 5. Temperature gradient profile in the cell from inlet to outlet

As the hydrogen is generated and methane is reacted with the steam reforming reaction occurring along the cell, the exothermic electrochemical reaction rate increases and endothermic reforming reaction rate decreases the temperature rises along the flow direction. After the entrance of the cell, the temperature of anode gas is close to the temperature of the cell and interconnects. The maximum and minimum temperatures of the cell are 1026 and $906 \mathrm{~K}$, respectively, resulting in a maximum temperature difference of $120 \mathrm{~K}$ along the cell. The average temperature gradient in the cell is approximately 1 $\mathrm{K} \mathrm{mm}^{-1}$.

Fig. 5 illustrates the temperature gradient profile in the cell from inlet to outlet. Temperature gradient is the important indicator for determining thermal stress in the 
material of the cell components. The modeling results show that along the length of the cell unit, at the mid-way of the cell (around $53 \mathrm{~mm}$ along the cell), the maximum temperature gradient (about $1.7 \mathrm{~K} \mathrm{~mm}^{-1}$ ) appears. Therefore, more attention should be paid to the midway of the cell in terms of the thermal stress induced crack of the cell. As for interconnects, which is made from metal with a good thermal conductivity, heat can be well dissipated through it, thus thermal stress is less important there. On the cathode side, the average temperature of cathode gas lags behind the solid parts and anode gas. Prior to the length of $19 \mathrm{~mm}$ along the cell, the temperature of cathode gas is higher than the cell and the temperature difference varies between $0 \mathrm{~K}$ and $50 \mathrm{~K}$. Afterwards the temperature of air is lower than the cell with air functioning as coolant and temperature different remains in the range of $10 \mathrm{~K}$.

\section{Conclusions}

A three-dimensional anode-supported intermediate-temperature planar SOFC cell unit model with direct internal reforming has been developed coupled with an electrochemical reaction model. The developed model can be used as a tool to investigate the thermal, fluid dynamics and electrochemical behavior of the proposed SOFC design operating at given conditions. The SOFC system studied in this work with inlet fuel and air temperatures of $973 \mathrm{~K}$ and $85 \%$ fuel utilization operated at an output voltage of 0.8 volt using the co-flow design has been reported. Modeling results of the gas species concentrations, the current density distribution, the temperature profiles and methane to steam ratios along the length of the cell unit are obtained. The reaction regions modeled in this work are distinguished in the SOFC cell instead of simply assuming surface reactions or solid reactions in the cell. It is found the relatively large temperature gradients can be caused by the combination and interaction of the different rates of the endothermic methane steam reforming reaction and exothermic electrochemical reaction at different locations in the cell. Therefore, the temperature gradients in SOFCs need to be carefully monitored to avoid any thermally induced fractures on the ceramic components.

\section{Acknowledgements}

This work was supported by SenterNovem (EOS-LT project).

\section{References}

1. S. C. Singhal and K. Kendall, eds., High Temperature Solid Oxide Fuel Cells: Fundamentals, Design and Applications. 1st ed. 2003, Elsevier Ltd., Oxford, UK.

2. U.S. DOE, National Energy Technology Laboratory, Fuel Cell Handbook, Seventh Edition. November, 2004

3. R. Peters, R. Dahl, U. Klüttgen, C. Palm, D. Stolten, J. of Power Sources, 106 (2002) 238-244.

4. H. Timmermann1, D. Fouquet, A. Weber, E. Ivers-Tiffée, U. Hennings, and R. Reimert, Fuel Cells, No. 3-4, (2006) 307-313. 
5. K. Nikooyeh, A. A. Jeje, J. M. Hill, J. of Power Sources, 171 (2007) 601-609.

6. E. Perry Murray, T. Tsai and S. A. Barnett, Nature, 400 (1999) 649-651.

7. V. M. Janardhanan, O. Deutschmann, J. of Power Sources, 162 (2006) 1192-1202.

8. J. Li, Y. Kang, G. Cao, X. Zhu, H. Tu, J. Li, J Zhejiang Univ. Sci. A, 9(7), (2008) 961-969.

9. P. Aguiara, C.S. Adjiman, N.P. Brandon, J. of Power Sources, 138 (2004) 120-136.

10. H. Yakabe, T. Ogiwara, M. Hishinuma, I. Yasuda, J. of Power Sources, 102 (2001) 144-154.

11. S. Campanari, P. Iora, J. of Power Sources, 132 (2004) 113-126.

12. G. Wang, Y. Yang, H. Zhang, W. Xia, J. of Power Sources, 167 (2007) 398-405.

13. B. Todd, J. B. Young, J. of Power Sources, 110 (2002) 186-200.

14. B. E. Poling, J. M. Prausnitz, J. P O'Connell, The Properties of Liquids \& Gas, $5^{\text {th }}$ Edition, McGraw-Hill, New York, 2000.

15. K. Ahmed, K. Foger, Catalysis Today, 63 (2000) 479-487.

16. J. Xu, G. F. Froment, AIChE Journal, 35, No. 1, (1989) 88-103.

17. A. L. Dicks, Journal of Power Sources, 71 (1998) 111-122.

18. J. M. Bodrov, L. O. Apel'baum and M.1. Tempkin, Kinetics and Catalvsis, 5(4) (1964) 614.

19. K. D. Poinron, Review of work on internal reforming in the solid oxide fuel cell, ETSU report F/01/00078/REP, 1997.

20. M. Hishinuma, T. Kawashima, I. Yasuda, Y, Matsuzaki and K. Ogasawara, SOFC-IV, 1995, pp. 153-162.

21. K. Ahmed, P. Seshadri. Y. Ramprakash. S. P. Jiang and K. Foger, SOFC-V, 1997, p. 228.

22. A. L. Dicks, K. D. Pointon, A. Siddle, J. of Power Sources, 86 (2000) 523-530.

23. E. Achenbach, E. Riensche, J. of Power Sources, 52 (1994) 283-288.

24. K. Ahmed, K. Foger, J. of Power Sources, 103 (2001) 150-153.

25. W. Lehnert, J. Meusinger, F. Thom, J. of Power Sources, 87 (2000) 57-63. 